\title{
O Palácio Itamaraty em Brasília: uma análise a partir da sintaxe da linguagem visual
}

Itamaraty Palace in Brasília, Brazil: an analysis in the light of visual language syntax

Palacio de Itamaraty en Brasilia, Brasil: un análisis a la luz de la sintaxis del lenguaje visual

Recebido em 30/10/2020 Aceito em 19/04/2021

BRANDÃO, Claudio Roberto Comas

Universidade Federal do Rio de Janeiro, Faculdade de Arquitetura e Urbanismo, Programa de Pós-graduação em Arquitetura. Rio de Janeiro, RJ, Brasil. claudio.brandao@fau.ufrj.br ORCID: 0000-0001-8306-0057 


\title{
Resumo
}

O Palácio Itamaraty, sede do Ministério das Relações Exteriores, é considerado uma das obras referenciais do arquiteto Oscar Niemeyer e é um dos edifícios de destaque na Esplanada dos Ministérios em Brasília. Este trabalho tem por objetivo analisar o edifício à luz das ferramentas da sintaxe visual. A análise se fundamenta nos atributos visuais e regras de composição descritos pela professora Donis A. Dondis em seu livro Sintaxe da linguagem visual e busca suprir a ausência de um memorial descritivo que explicite as intenções do arquiteto. $O$ objeto de estudo é analisado em três escalas: no contexto urbano, na composição dos volumes do complexo do ministério e na escala do edifício, neste caso, o palácio. Espera-se com isso complementar as recentes pesquisas sobre o Palácio Itamaraty e dar subsídios a novas hipóteses sobre este objeto.

Palavras-Chave: Palácio Itamaraty, Sintaxe da linguagem visual, Arquitetura moderna, Brasília

\begin{abstract}
The Itamaraty Palace, headquarters of the Ministry of Foreign Affairs, is considered as one of Brazilian architect Oscar Niemeyer's referential works and it is a highlight at the Ministries Esplanade in Brasilia, Brazil's Federal District. The aim of this study is to analyze the building in the light of the visual syntax tools. The analysis is based on the visual attributes and composition rules described by Professor Donis A. Dondis in her book A Primer of Visual Literacy and seeks to fulfil the lack of a document expressing the architect's intention. The object of study is analyzed on three scales: the urban context, the composition of volumes of the ministries' buildings complex, and the scale of the building, in this specific case the palace. The purpose is to complement recent research on the Itamaraty Palace and provide elements for new hypothesis about this object.
\end{abstract}

Keywords: Itamaraty Palace, Visual language syntax, Modern architecture, Brasília

\section{Resumen}

El Palacio de Itamaraty, sede del Ministerio de Relaciones Exteriores, es considerado una de las obras referenciales del arquitecto brasileño Oscar Niemeyer y es un punto culminante en la Explanada de los Ministerios en Brasilia, Distrito Federal de Brasil. El objetivo de este estudio es analizar el edificio a la luz de las herramientas de sintaxis visual. El análisis se basa en los atributos visuales y las reglas de composición descritas por el profesor Donis A. Dondis en su libro Sintaxis del lenguaje visual y busca suplir la falta de un documento que exprese la intención del arquitecto. El objeto de estudio se analiza en tres escalas: el contexto urbano, la composición de volúmenes del conjunto de edificios de los ministerios y la escala del edificio, en este caso concreto el palacio. El propósito es complementar las investigaciones recientes sobre el Palacio de Itamaraty y aportar elementos para nuevas hipótesis sobre este objeto.

Palabras clave: Palacio de Itamaraty, Sintaxis del lenguaje visual, Arquitectura moderna, Brasilia 
Perceber, simples e imediatamente, a arquitetura, como tal, é operação que precisa de alto treino; e significa senti-la agindo sobre nós, como massa, linha, plano, cor, espaço.

Mario Pedrosa

\section{Introdução}

No conjunto de monumentos arquitetônicos dispostos ao longo do Eixo Monumental de Brasília destacam-se, além das sedes dos três poderes da República, os palácios da Justiça e Itamaraty, situados na cabeceira da Esplanada dos Ministérios. Neste artigo nos dedicaremos especialmente ao Palácio Itamaraty, sede representativa do Ministério das Relações Exteriores. Esta investigação se insere em uma pesquisa mais ampla, que vem sendo realizada a nível de doutorado, sobre o complexo do Ministério das Relações Exteriores. ${ }^{1}$

O Palácio Itamaraty (Figura 1) se difere dos demais palácios do Eixo Monumental de Brasília projetados por Oscar Niemeyer, que são caracterizados pela adoção de formas insólitas e espetaculares na estrutura, sobretudo das colunas ou em elementos secundários, como é o caso das rampas, do parlatório no Palácio do Planalto e das cascatas de concreto do Palácio da Justiça. Não há, no Itamaraty, elementos sobressalentes ou variações no ritmo nas fachadas, que por sua vez são todas iguais e caracterizadas por arcos plenos, clássicos. O edifício anexo funciona como pano de fundo, sem protagonizar a composição, como acontece com as torres do Congresso. Não há surpresas volumétricas. A princípio, o conjunto do Ministério das Relações Exteriores parece se destacar mais pela sobriedade do que pela invenção.

Figura 1: Complexo do Ministério das Relações Exteriores (com destaque em cores). No fundo à esquerda o Anexo II, no centro o Anexo I e à direita, junto à pista, o Palácio Itamaraty.

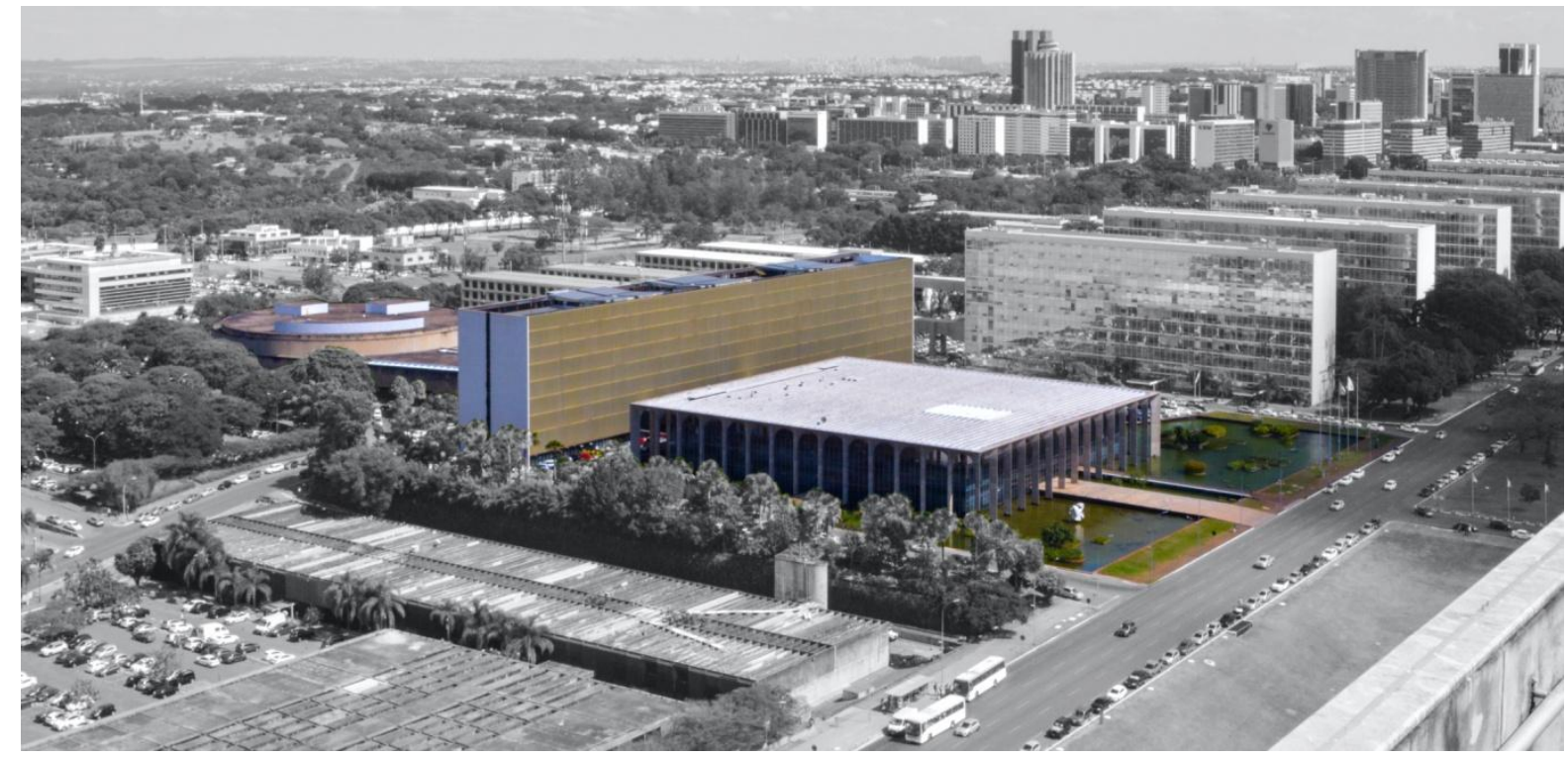

Foto do autor

\footnotetext{
${ }^{1}$ Este artigo foi elaborado a partir de leituras e análises propostas pela professora Maria Angela Dias no âmbito da disciplina Categorias morfológicas estruturais: atributos geométricos da forma dos lugares, do Proarq / UFRJ.
} 
Oscar Niemeyer (1907-2012), autor do projeto, não deixou o costumeiro memorial descritivo que acompanhava suas principais obras e que publicava na Módulo, revista comandada por ele. Construído após a inauguração de Brasília, o Itamaraty também não aparece em seus primeiros depoimentos sobre as obras da capital. O que encontramos de escrito a respeito do projeto em nossas pesquisas é um breve parágrafo manuscrito em uma prancha de estudo que explica a estratégia de distribuição dos ambientes de trabalho, blocos de sanitários e ambientes de apoio ${ }^{2}$. Os textos explicativos de Niemeyer, como sabemos, faziam parte do seu método de trabalho. Como ele próprio explica, "Terminados os desenhos e cortes, começo a escrever o texto explicativo. É a minha prova dos nove, pois se não encontro argumentos para explicar o projeto, é natural que eu reveja, pois lhe falta alguma coisa importante" (NIEMEYER, 1980, p. 89). Anos depois da inauguração, em uma das poucas referências que faz ao Itamaraty, Niemeyer (2000, p. 41) o descreve como "essa arquitetura elegante e repetida que anda por aí. Fácil de ser elaborada e aceita pela grande maioria".

Mas não é esse o lugar reservado ao edifício na historiografia. O arquiteto Olavo Redig de Campos (1968, p. 20), colaborador do projeto, considerava o Itamaraty "a melhor obra de Oscar Niemeyer". Yves Bruand (1981, p. 198) identifica uma mudança de vocabulário em Niemeyer com a superação "do estágio psicológico de reação absoluta contra toda lembrança histórica", e acrescenta que "parece ser unânime a concordância quanto ao sucesso estético do Palácio dos Arcos" ${ }^{3 "}$. Na revista Acrópole, comemorativa do $10^{\circ}$ aniversário de Brasília, Cláudio Gomes (1970, p. 29) concorda que o "Palácio dos Arcos de Niemeyer, resultou no mais requintado edifício do Eixo Monumental". David Underwood (2002, p. 42) trata superficialmente do edifício, provavelmente por não aderir à sua tese de um "modernismo de formas livres", mas reafirma a observação de Bruand e enxerga no vocabulário clássico dos arcos uma dignificação das funções do ministério, fazendo com "que sobressaiam na hierarquia de formas de Brasília".

Pesquisas mais recentes têm procurado superar as análises baseadas somente na obra construída a partir de estudos mais rigorosos do processo de elaboração do projeto. Nesse sentido, Eduardo Pierrotti Rossetti e Graça Ramos (2017) ressaltam a importância das colaborações para o sucesso do empreendimento, destacando a atuação do já mencionado Redig de Campos, arquiteto interno do Itamaraty, de Milton Ramos, arquiteto da empresa construtora e do embaixador Wladimir Murtinho, por sua reconhecida coordenação geral. Seguindo esse caminho, a pesquisa deste autor demonstra que a arquitetura do Itamaraty não foi tão fácil de ser elaborada como afirma Niemeyer. Do primeiro risco, de 1959, à sua versão definitiva, de 1965, foram identificadas oito versões distintas, das quais algumas se desdobraram em variantes, somando doze esquemas diferentes ${ }^{4}$.

De acordo com as análises acima, o lugar de destaque do Itamaraty na obra palaciana de Niemeyer é garantido, sobretudo, pelo esmero no desenvolvimento do projeto, pela qualidade da execução, pela atuação do cliente durante o processo e pela tradição da instituição, que teria pesado nas decisões de projeto.

A proposta deste trabalho difere um pouco das demais. Trata-se de uma análise puramente visual do edifício em diversas escalas. A respeito desse tipo de análise, lembramos a importância da visualidade

\footnotetext{
${ }^{2}$ A inscrição consta em uma prancha em papel manteiga que se encontra no arquivo do arquiteto Milton Ramos, que diz: "A preocupação básica é manter no projeto um critério de flexibilidade que permita atualizá-lo de acordo com as exigências de trabalho. Isso obriga, naturalmente, a uma solução mais simples, localizando sanitários, afins, etc., de forma a não criar obstáculos às modificações necessárias, modificações que a pátria nos faz considerar [ilegível] e repetidas, de acordo com pontos de vista pessoais." (NIEMEYER, s.d.)

${ }^{3}$ Antes de se chamar oficialmente Palácio Itamaraty, nome herdado da antiga sede do Ministério das Relações Exteriores no Rio de Janeiro, o edifício era conhecido como Palácio dos Arcos.

${ }^{4}$ BRANDÃO, Claudio Roberto Comas. O Palácio Itamaraty em Brasília: reflexões sobre a concepção arquitetônica. Dissertação de mestrado. Rio de Janeiro: UFRJ, 2019.
} 
para Oscar Niemeyer. Em seus memoriais de projeto, além de explicar as soluções funcionais, de adequação ao terreno e a tecnologia construtiva, o arquiteto frequentemente demonstrava os efeitos visuais desejados a partir de croquis (Figura 2). O domínio da forma que Niemeyer demonstra ter, certamente foi adquirido na sólida formação acadêmica que recebeu e durante sua extensa prática profissional, mas isso não seria suficiente sem um grande empenho na elaboração dos projetos. Esse empenho tem sido verificado na documentação de projeto levantada em pesquisas, assim como nos já mencionados memoriais de projeto. Além destes, o arquiteto produziu vários textos de caráter didático. Em A imaginação na arquitetura (NIEMEYER, 1959), por exemplo, descreve como explora o efeito de paralaxe ${ }^{5}$ produzido pelo distanciamento das colunas em relação ao corpo do edifício. No texto Espaço arquitetural (NIEMEYER, 1978) que faz parte de uma série chamada "problemas da arquitetura", publicada na Módulo entre 1978 e 1980 e compiladas no livro "Como se faz arquitetura" (NIEMEYER, 1986), Niemeyer explica a estratégia do 'contraste espacial' para a exaltação da grandeza, luminosidade e colorido de um ambiente. Nesses textos, Niemeyer dá preferência a uma linguagem "simples e didática" e rejeita "as digressões da filosofia e da ginástica intelectual" (NIEMEYER, 1978, p. 54).

Figura 2: Sequência de visadas do Palácio do Supremo Tribunal Federal em Brasília
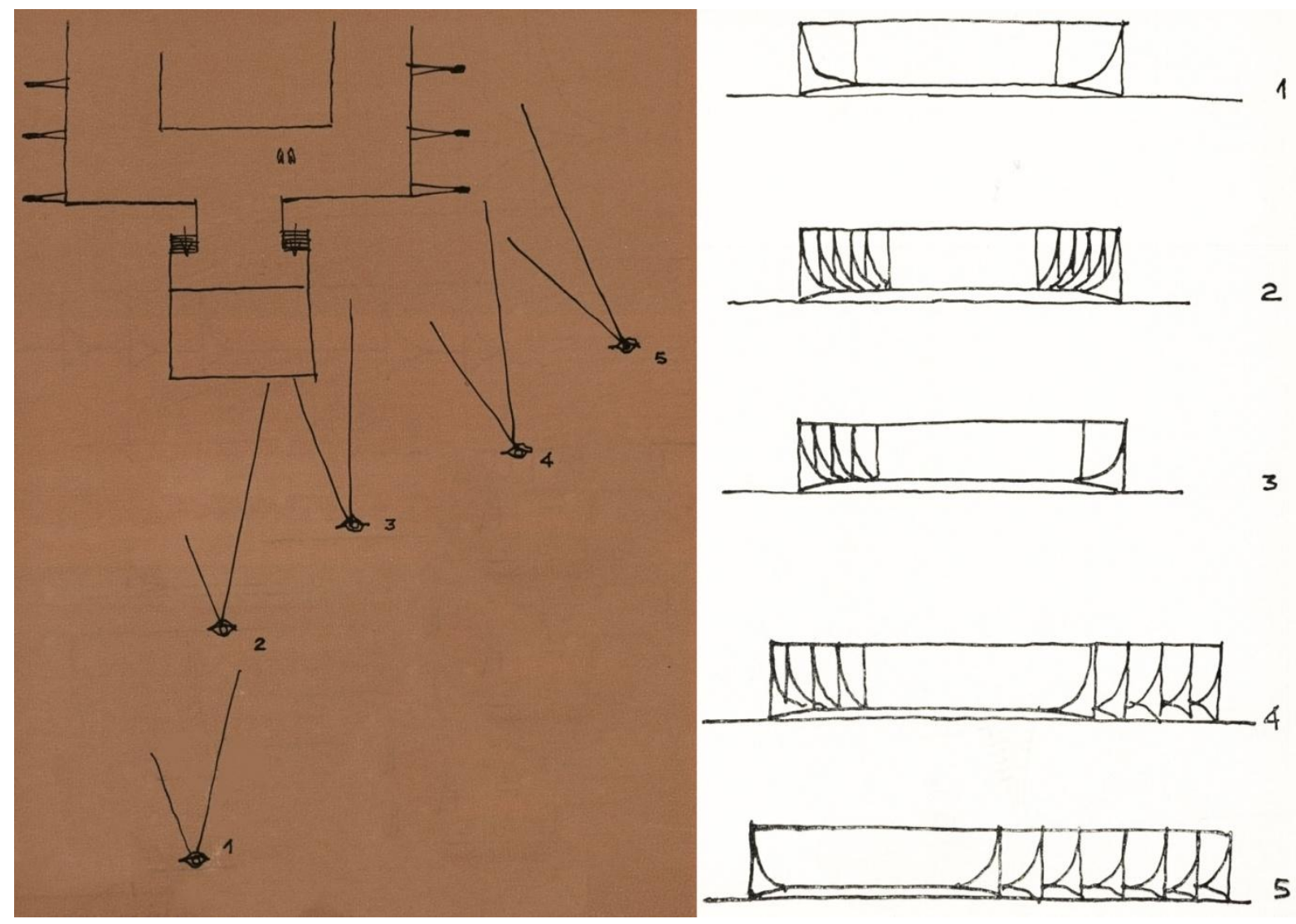

Fonte: (NIEMEYER, 1959, p. 10-11)

\footnotetext{
${ }^{5}$ Paralaxe é o fenômeno de deslocamento aparente de objetos em relação ao fundo que acontece com a mudança do ponto de vista. Peter Collins defende que a crescente exploração desse fenômeno visual, a partir da metade do séc. XVIII, só foi possível com o desenvolvimento das técnicas de construção em aço e concreto armado e que isso teve crucial importância no surgimento dos novos conceitos de espaço aplicados na arquitetura moderna. Cf. COLLINS, Peter. Los ideales de la arquitectura moderna; su evolución (1750-1950). Barcelona: Gustavo Gili, 5. ed., 1998.
} 
Talvez esse aspecto didático e objetivo de Oscar Niemeyer não corresponda à imagem que se criou em torno do arquiteto, sobretudo em sua última fase da carreira. A figura do gênio romântico, muitas vezes reverberada por críticas superficiais de suas obras, mas também sustentada pelo arquiteto, que parecia projetar sem esforço, às vezes durante os sonhos, é a que ficaria impressa no imaginário comum. Em sua produção textual mais recente, a linguagem poética - de forte poder imagético, e talvez seja esse o motivo - e a despretensão teórica tomam o lugar da objetividade de seus textos anteriores. O fragmento de entrevista publicado na Módulo em 1975: "Não é o ângulo reto que me atrai, nem a linha reta, dura, inflexível, criada pelo homem. O que me atrai é a curva livre e sensual, a curva que encontro nas montanhas do meu país, no curso sinuoso dos seus rios, nas ondas do mar, no corpo da mulher preferida" (NIEMEYER, 1975, p. 43), se tornaria sua marca registrada. Miguel Alves Pereira (1997, p. 124) afirma que "esse fragmento de entrevista viria a constituir-se, nos anos subsequentes, no texto mais citado e recitado de Oscar, e repetido por ele mesmo à exaustão". Em certa medida, esta pesquisa procura desmistificar essa imagem do arquiteto, não no sentido de desfazer a imagem do gênio, mas de torná-la mais rica e complexa.

\subsection{O método de análise adotado e suas limitações}

A sintaxe da linguagem visual faz a relação entre imagem e linguagem. A sintaxe, nos informa a enciclopédia, "é a parte da gramática que estuda a disposição das palavras na frase e das frases no discurso, incluindo a sua relação lógica, entre as múltiplas combinações possíveis para transmitir um significado completo e compreensível" ${ }^{\prime 6}$. As imagens são regidas por regras de construção e, assim como as línguas naturais, ou as linguagens de programação e a matemática, têm o poder de comunicar, de informar. Para compreender esse vocabulário é necessário conhecer seus elementos e regras de composição. A professora Donis A. Dondis (1997) procura sistematizar essas regras compositivas em seu livro Sintaxe da linguagem visual, utilizado neste trabalho para fundamentar nossas análises.

Um dos limites da aplicação dos conceitos propostos por Dondis, é que eles são apresentados a partir da observação de imagens bidimensionais. Para a percepção do espaço arquitetural é preciso levar em conta não somente a ação sobre nossos sentidos das linhas, planos e massas, como em uma fotografia, mas também os efeitos variados produzidos pelo movimento do observador. Portanto, elegemos as ferramentas que mais se adequam à verificação na arquitetura e procuramos descrever, sempre que possível, a percepção do espaço a partir de múltiplos pontos de vista. Os conceitos adotados são: repouso e tensão; nivelamento e aguçamento; e contraste e harmonia, que serão explicados a seguir.

Pode-se argumentar, em oposição à nossa proposta, que seu caráter subjetivo inviabilizaria a análise. Com efeito, o nível de subjetividade do juízo estético, certamente superior ao da avaliação objetiva de aspectos técnicos, tende a ser contestado. É possível que essa barreira resulte do fato que o alfabetismo visual, à diferença de outros tipos de linguagem, escrita, matemática e até de programação, não é normalmente ensinado. Sem fechar os olhos para a complexidade da arquitetura, é preciso levar em conta que a falta de domínio desse tipo de vocabulário tende à valorização da intuição, do talento individual e da genialidade, o que pode ser frustrante para uma grande parcela dos estudantes de arquitetura. De acordo com Dondis (1997, p. 17), "grande parte da comunicação visual foi deixada ao sabor da intuição e do acaso".

\footnotetext{
${ }^{6}$ Fonte Wikipedia: <https://pt.wikipedia.org/wiki/Sintaxe> acesso em 04 jan 2020.
} 


\title{
2. Alguns fundamentos da composição visual
}

\begin{abstract}
A sintaxe visual existe. Há linhas gerais para a criação de composições. Há elementos básicos que podem ser aprendidos e compreendidos por todos os estudiosos dos meios de comunicação visual, sejam eles artistas ou não, e que podem ser usados, em conjunto com técnicas manipulativas, para a criação de mensagens visuais claras. O conhecimento de todos esses fatores pode levar a uma melhor compreensão das mensagens visuais. (DONDIS, 1997, p. 18)
\end{abstract}

Dondis (1997, p. 23) elenca os seguintes elementos: o ponto, a linha, a forma, a direção, o tom, a cor, a textura, a proporção, a dimensão e o movimento, que integram a "caixa de ferramentas" de qualquer composição visual. A maneira de compor estes elementos pode se baseia em fundamentos compositivos. Nós utilizaremos alguns destes fundamentos para descrever o nosso objeto de estudo.

\subsection{Repouso e tensão}

O equilíbrio é a tendência humana a organizar a visão a partir de dois eixos principais: um eixo vertical, perpendicular à força da gravidade e um eixo horizontal, paralelo ao horizonte, portanto estável. De acordo com Dondis (1997, p. 32), o equilíbrio é "a mais importante influência tanto psicológica como física sobre a percepção humana, [...] a referência visual mais forte e firme do homem, sua base consciente e inconsciente para fazer avaliações visuais".

Esta última afirmação é particularmente importante porque nos explica que o efeito de equilíbrio pode ser consciente, facilmente identificável em formas estáveis, onde a noção de equilíbrio é explícita; ou ainda inconsciente, quando buscamos o equilíbrio em formas instáveis. Mesmo nesses casos - onde há dificuldade de se relacionar a forma aos eixos vertical e horizontal - existe uma busca instintiva pelo equilíbrio visual. Podemos afirmar assim que, a partir da busca constante pelo equilíbrio, identificamos duas polaridades perceptivas: o repouso e a tensão. O repouso exige menos esforço perceptivo, enquanto a tensão, ao exigir uma resposta constante do observador, tem maior poder atrativo (Figura 3). Mesmo em composições instáveis, ou sob tensão, é possível identificar algum equilíbrio, o que é diferente de composições desordenadas a ponto de inibir a identificação de uma forma.

Figura 3: Repouso e tensão

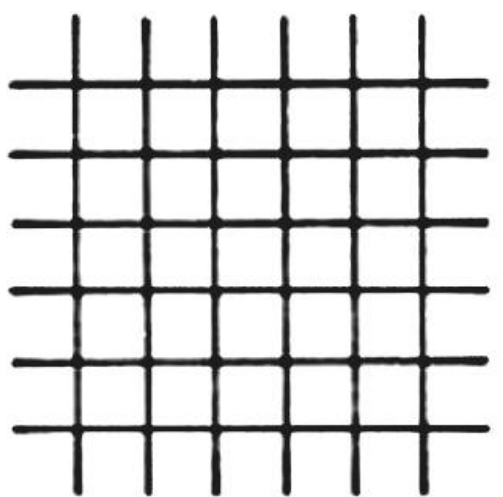

(REPOUSO)

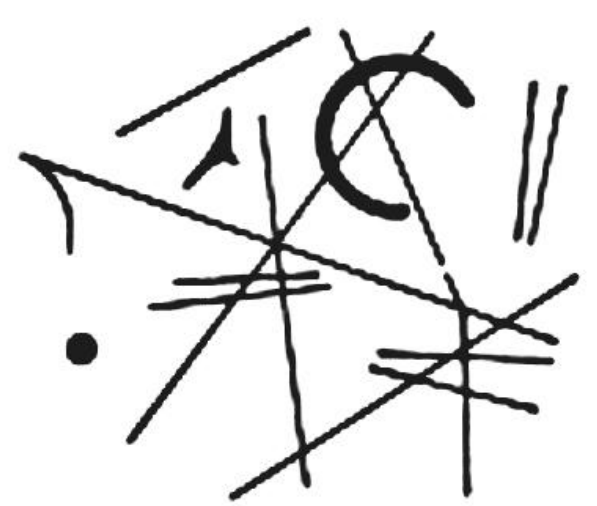

(TENSÃO) 


\subsection{Nivelamento e aguçamento}

A antítese nivelamento/aguçamento, utilizada por psicólogos, está relacionada com a noção de repouso e de tensão. Segundo Dondis (1997, p. 113), "aguçamento pode equivaler a contraste, e nivelamento pode ser associado a harmonia". Podemos traduzir o conceito de aguçamento como uma certa surpresa ao se observar um objeto ou imagem. Por exemplo, uma porta deslocada do eixo simétrico em uma fachada regular, ou um objeto de cor diferente junto a uma sequência de objetos iguais, produzem o efeito de aguçamento. Aguçamento é o conceito que exprime a não previsibilidade de um objeto. Assim como no caso da tensão, somos atraídos por formas que exigem uma resposta cognitiva para tal imprevisibilidade. O aguçamento é particularmente visível em desvios inseridos em formas regulares, como um ponto fora do centro.

A origem do efeito de aguçamento da percepção é inconsciente. A reação a um ruído estranho ou a um movimento inesperado, captado pela visão, é um instinto necessário para escapar de situações perigosas ou para capturar uma presa, por exemplo. Ao superar essa reação instintiva, somos recompensados com uma sensação de prazer. Isso nos ajuda a entender porque crianças adoram pregar sustos nos outros ou a paixão de algumas pessoas por atividades extremas. No campo das artes, o aguçamento explica a sensação prazerosa que algumas composições musicais nos provocam, como na música de João Gilberto ${ }^{7}$, quando propositalmente descompassa a métrica do vocal da batida do violão para, em seguida, sincronizá-las.

$O$ aguçamento na linguagem visual nos coloca em constante atenção, faz com que uma forma, um quadro, um objeto, um edifício, se destaque dos demais. Aguçamento e tensão podem transmitir paixão, raiva, energia, alegria; mas em excesso, são cansativos.

O nivelamento, por sua vez, é a ausência de tensão. Formas estáveis, niveladas, transmitem tranquilidade, exigem pouca energia do observador. A estabilidade nos permite descansar o olhar e dedicar nossa energia para outras ações. Sem causar surpresas, no entanto, formas estáveis podem passar despercebidas, pois tendem a se harmonizar com o ambiente. As formas estáveis na arquitetura transmitem cotidianidade, neutralidade, previsibilidade (Figura 4).

Figura 4: Nivelamento e aguçamento
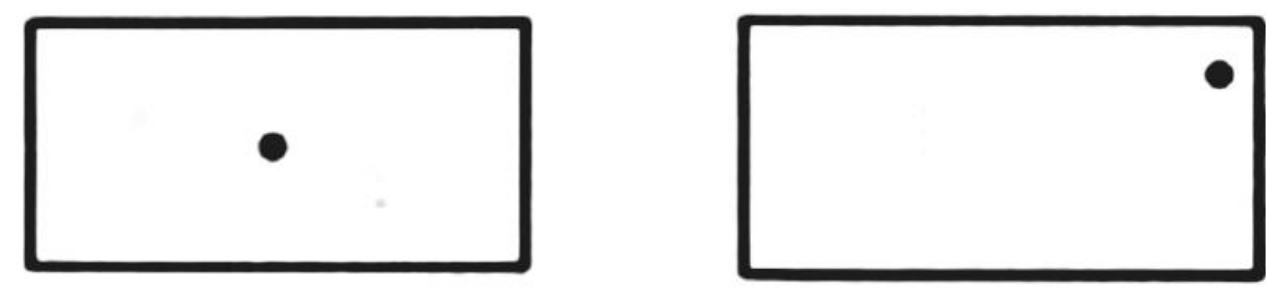

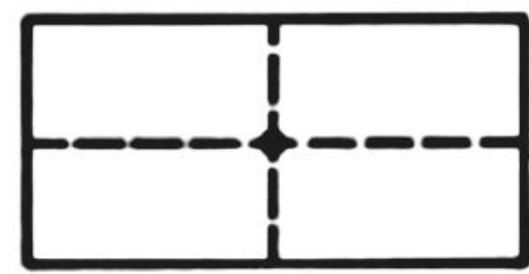

(NIVELAMENTO)

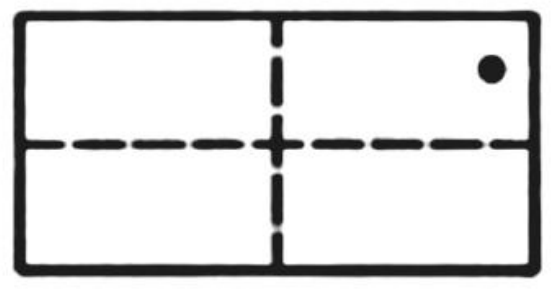

(AGUÇAMENTO)

Fonte: DONDIS, 1997, p. 35.

\footnotetext{
7 João Gilberto (1931-2019) foi um compositor, violonista e cantor brasileiro que se destacou no cenário musical a partir do final dos anos 1950 a o criar uma nova batida de violão para o samba que ficou conhecida como bossa nova. Uma das características de sua música é a ruptura da cadência regular do samba, obtida pelo descompasso da voz e do violão, o que exigia um domínio absoluto do ritmo e técnicas vocais aprimoradas.
} 


\subsection{Contraste e harmonia}

A estratégia para acentuar a diferença entre o nivelamento e o aguçamento, entre o repouso e a tensão é o contraste, e é frequentemente explorada em diversos campos da arte. Na música, por exemplo, com as súbitas mudanças de ritmo; na pintura, explorando as linhas diagonais em contraste com as bordas ortogonais, ou na dança, destacando um ou mais bailarinos do grupo que executam movimentos diferentes.

Em arquitetura, pode-se obter contraste recuando o plano de alinhamento de um edifício em relação aos seus vizinhos, ou diferenciando-o por forma, cor ou altura. No projeto da Catedral de Brasília, por exemplo, Niemeyer (1978, p. 56) explica que "se o arquiteto desejar dar ao volume interior que criou maior imponência, uma das soluções é o contraste espacial, isto é, projetar um acesso mais estreito, dando ao visitante - pelo contraste - a impressão da amplitude desejada" (Figura 5). No entanto, assim como acontece com o aguçamento e com a tensão, o contraste em excesso pode causar anestesia, quando bem dosado pode ser uma estratégia eficiente para chamar a atenção do observador.

Figura 5: O uso do contraste na Catedral de Brasília

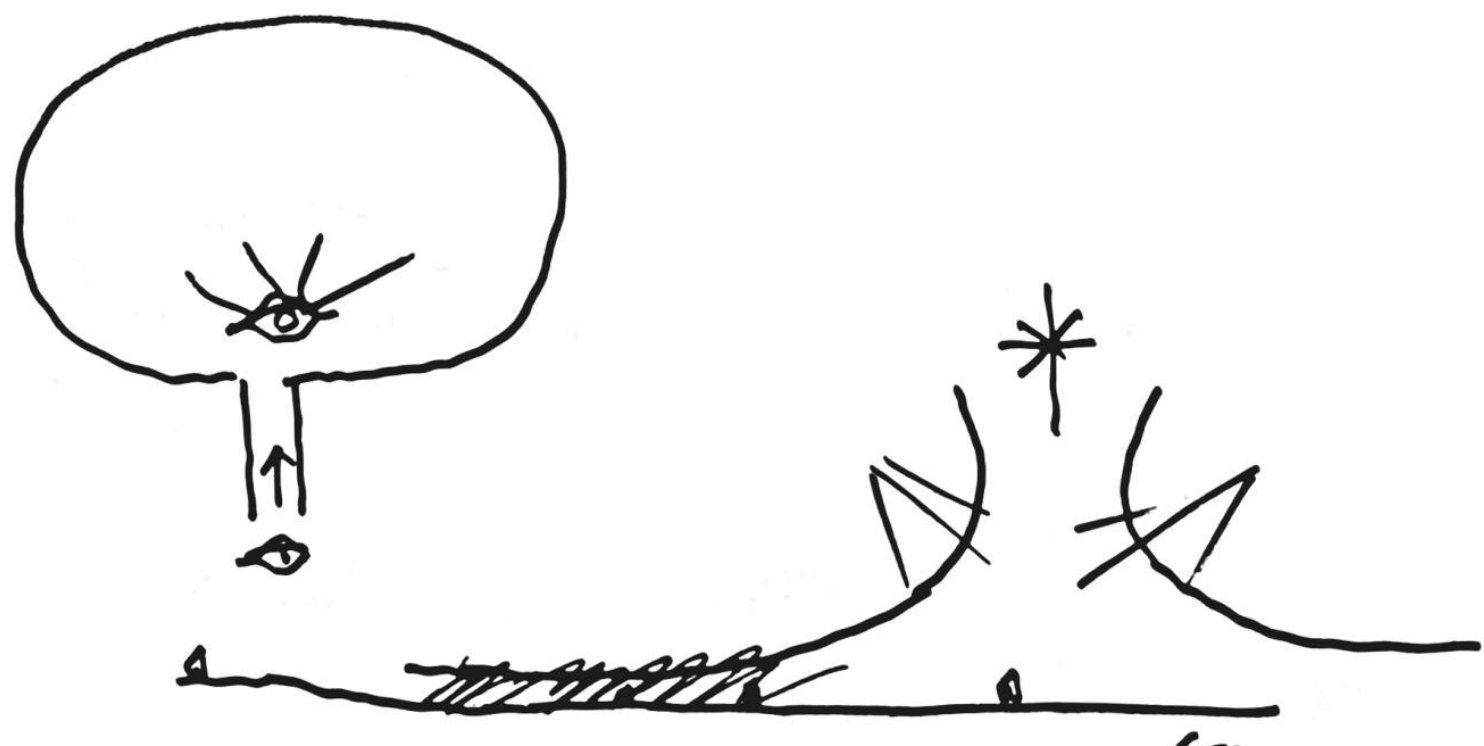

(15)

Fonte: (NIEMEYER, 1978, p.57)

\section{Análise do Palácio Itamaraty}

O Palácio Itamaraty é a sede representativa do Ministério de Relações Exteriores em Brasília e faz parte de um complexo de três edifícios interligados por passadiços, projetados em fases distintas por Oscar Niemeyer. Na primeira fase, que vai de 1959 até 1970, foram projetados e construídos o palácio e o primeiro anexo, dedicado à função administrativa, e que serão objeto desta análise. A partir de 1974 foi projetado o segundo anexo, dedicado ao serviço de comunicação do ministério, inaugurado em 1986. 


\subsection{O Palácio Itamaraty e o projeto original de Lucio Costa}

Ao longo dessa esplanada - o Mall dos ingleses - extenso gramado dedicado aos pedestres, a paradas e a desfiles, foram dispostos os ministérios e autarquias. Os das Relações Exteriores e Justiça ocupando os cantos inferiores, contíguos ao edifício do Congresso e com enquadramento condigno. (COSTA, 1995, p. 289)

Nossa análise começa pela inserção do edifício na escala urbana. Situados na cabeceira da Esplanada dos Ministérios, o Palácio Itamaraty e o Palácio da Justiça fazem a transição entre a sequência de blocos padronizados dos ministérios e a Praça dos Três Poderes, ápice do Eixo Monumental de Brasília (Figura 6).

Figura 6: Trecho do Plano Piloto de Lucio Costa relativo ao Eixo Monumental com destaque para o Palácio Itamaraty feito pelo autor.

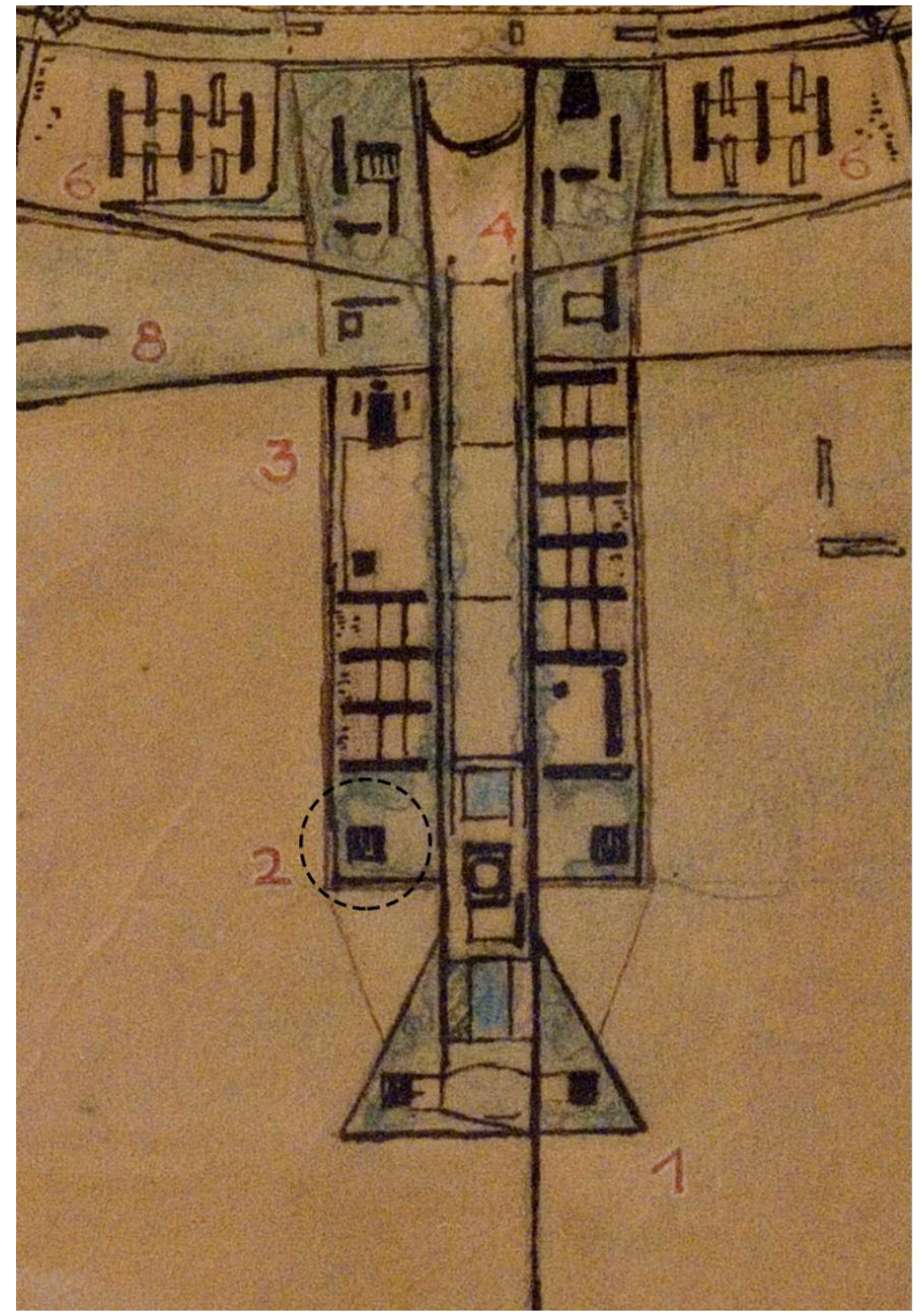

Legenda:

1. Praça do Três Poderes

2. Esplanada dos Ministerios

3. Catedral

4. Setor Cultural

5. Centro de Diversores

6. Setor de Bancos e Escritórios

7. Setor Comercial

8. Hoteis

Fonte: Casa de Lucio Costa com destaque feito pelo autor.

No plano de Lucio Costa (1902-1998), o Eixo Monumental, que comporta a Esplanada dos Ministérios e a Praça dos Três Poderes, é cortado pelo Eixo Residencial, mais longo e curvado para se adequar ao terreno. Essa forma em cruz, estável e simétrica, permite que o plano de Brasília seja facilmente apreendido, não somente entre os profissionais do campo, mas também que se fixe na imaginação popular (Figura 7). 
Figura 7 Plano Piloto da nova capital do Brasil - Lucio Costa, 1957.

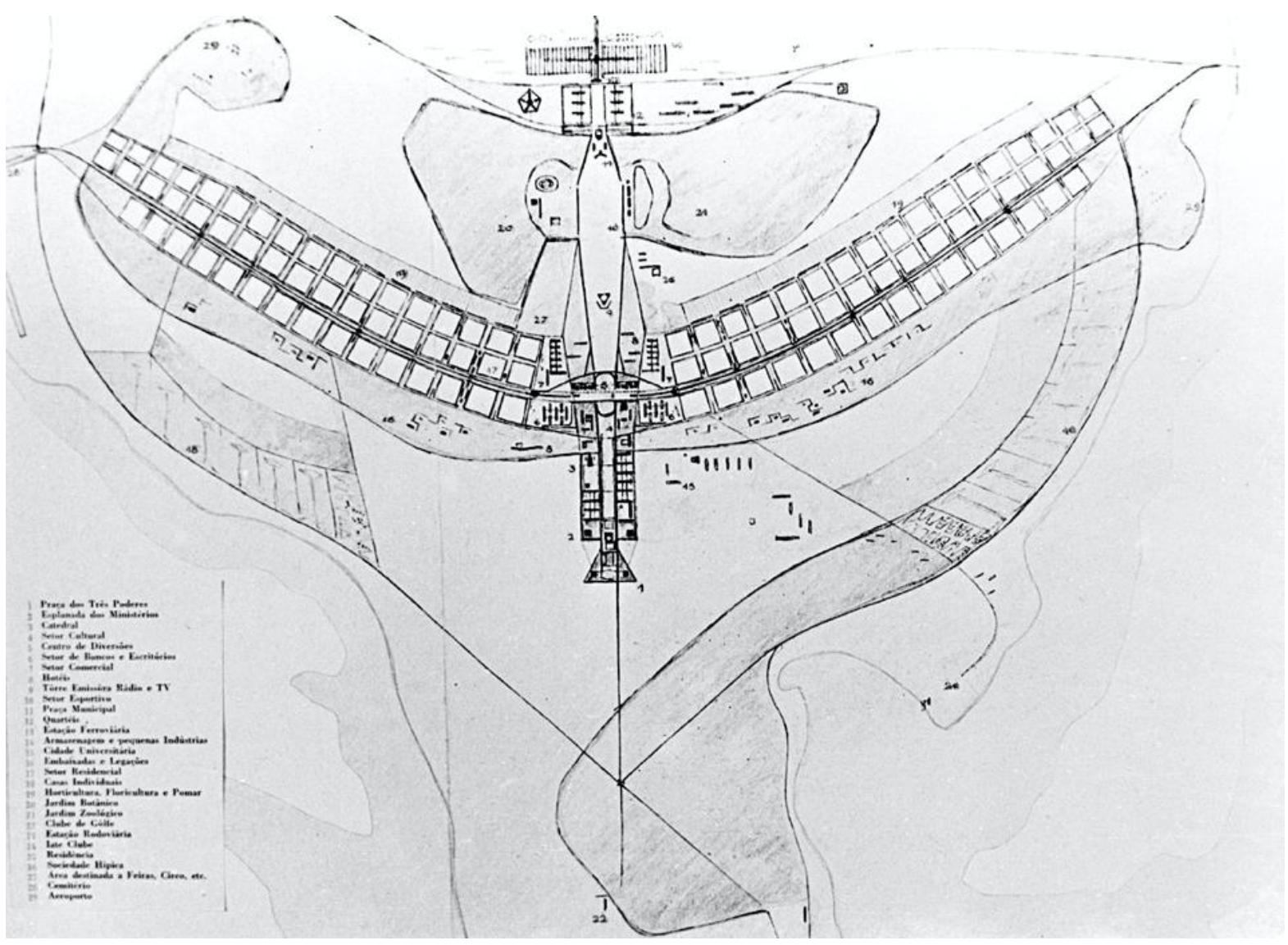

Fonte: Arquivo Público do Distrito Federal

Observando mais atentamente o desenho original de Costa, notamos que a disposição dos ministérios e palácios ao longo do Eixo Monumental não é absolutamente simétrica. Lucio Costa rompe com a simetria criando uma praça para os ministérios militares e diferenciando a sequência de blocos, maior de um lado do que do outro. Nessa versão, os ministérios da Justiça e das Relações Exteriores têm a mesma forma e estão simetricamente distanciados do eixo e dos blocos vizinhos. O Palácio do Congresso, na concepção de Costa, teria uma única cúpula para o plenário, apoiada sobre uma plataforma horizontal e uma torre deslocada ao sul do eixo de simetria (Figura 8). 
Figura 8: Perspectiva do Eixo Monumental realizada por Lucio Costa - 1957, com destaque para o Palácio Itamaraty feito pelo autor

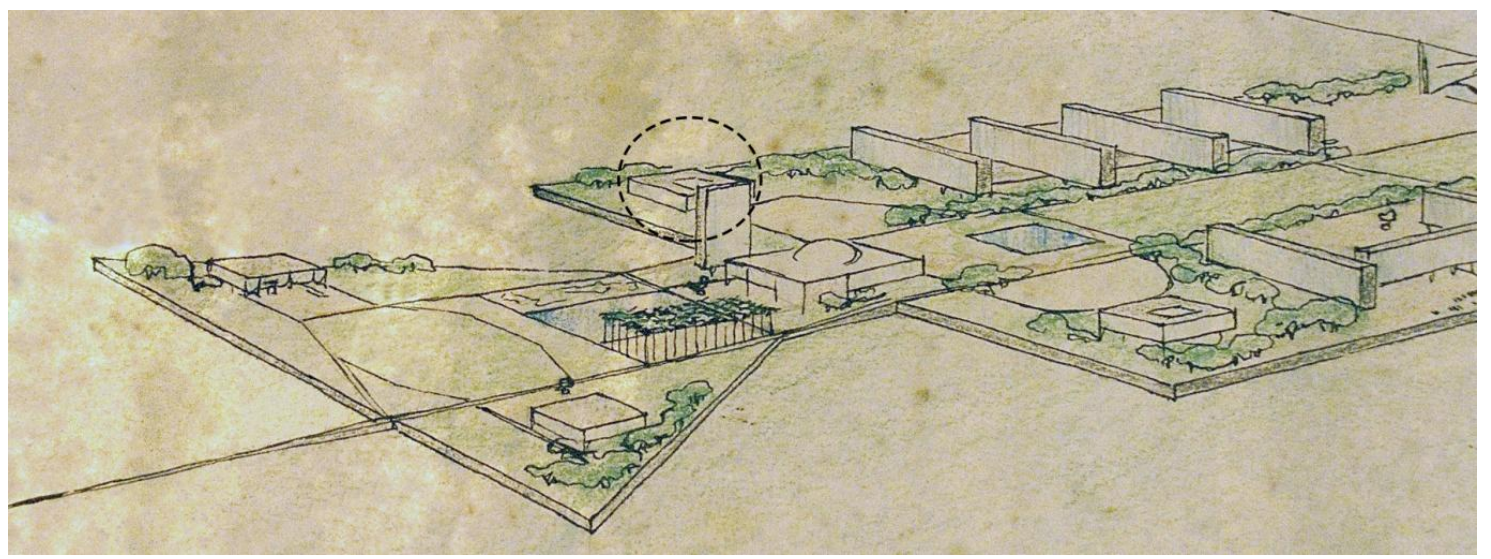

Fonte: Casa de Lucio Costa

Podemos classificar os edifícios da Esplanada dos Ministérios em três tipos: templos, palácios e escritórios, cada qual com sua particularidade formal e de localização. A Catedral, ou o templo, tem formas mais exuberantes e posição privilegiada na composição, com amplo espaço reservado para a sua implantação. O mesmo acontece com os palácios, também colocados em posição de destaque, porém com formas mais sóbrias. Os ministérios ocupam blocos de escritórios padronizados e desprovidos de caráter individual, mas que em conjunto têm a força da repetição da forma e constância do distanciamento. Os ministérios das Relações Exteriores e o da Justiça são considerados especiais por sua importância na República e, portanto, ocupam palácios.

Ao fazer uma leitura da composição no sentido da Catedral à Praça dos Três Poderes, notamos algumas estratégias adotadas para valorizar os palácios. A primeira é o recuo das fachadas em relação ao plano de alinhamento dos escritórios, a segunda é a mudança de ritmo, com o aumento do espaço entre os blocos e, por fim, a mudança de forma e tamanho. Esse contraste volumétrico e espacial confere aos palácios um sentido de monumentalidade sem que se imponham pelo tamanho.

A Catedral, a torre do Congresso e os ministérios militares quebram a simetria do conjunto. A torre do Congresso, colocada do lado oposto lado dos blocos em "U" dos ministérios militares, equilibra a composição. Essas pequenas variações de um lado e do outro do eixo provocam o efeito de aguçamento e exigem do receptor da mensagem visual um certo esforço para reorganizar a imagem em uma unidade, o que a teoria da gestalt define como pregnância. Podemos concluir que, ao negar a simetria absoluta e ideal, a disposição dos volumes ao longo do Eixo Monumental nos convoca a participar e avaliar a composição. Apoiando-se na força da composição simétrica, Lucio Costa introduz algumas surpresas e confirma que "o poder do previsível empalidece diante do poder da surpresa", conforme Dondis (1997, p. 37).

\subsection{A configuração definitiva da Esplanada dos Ministérios}

Com o desenvolvimento dos projetos dos palácios, a composição original proposta por Lucio Costa sofre alterações. O canteiro central do Mall é alargado de $180 \mathrm{~m}$ para $200 \mathrm{~m}$ de modo a se adequar ao novo desenho da plataforma do Palácio do Congresso (MACEDO e SILVA, 2010). A sequência dos ministérios padronizados torna-se mais simétrica e repetitiva e desaparece a praça entre os ministérios militares, agora dispostos paralelos aos demais. É mantida a assimetria da sequência de ministérios, maior de um lado que do outro, assim como a posição destacada da catedral e dos palácios da Justiça e Itamaraty. No caso destes últimos, o recuo em relação ao plano de alinhamento é praticamente anulado e o aumento da escala diminui o efeito contrastante. (Figura 9) 


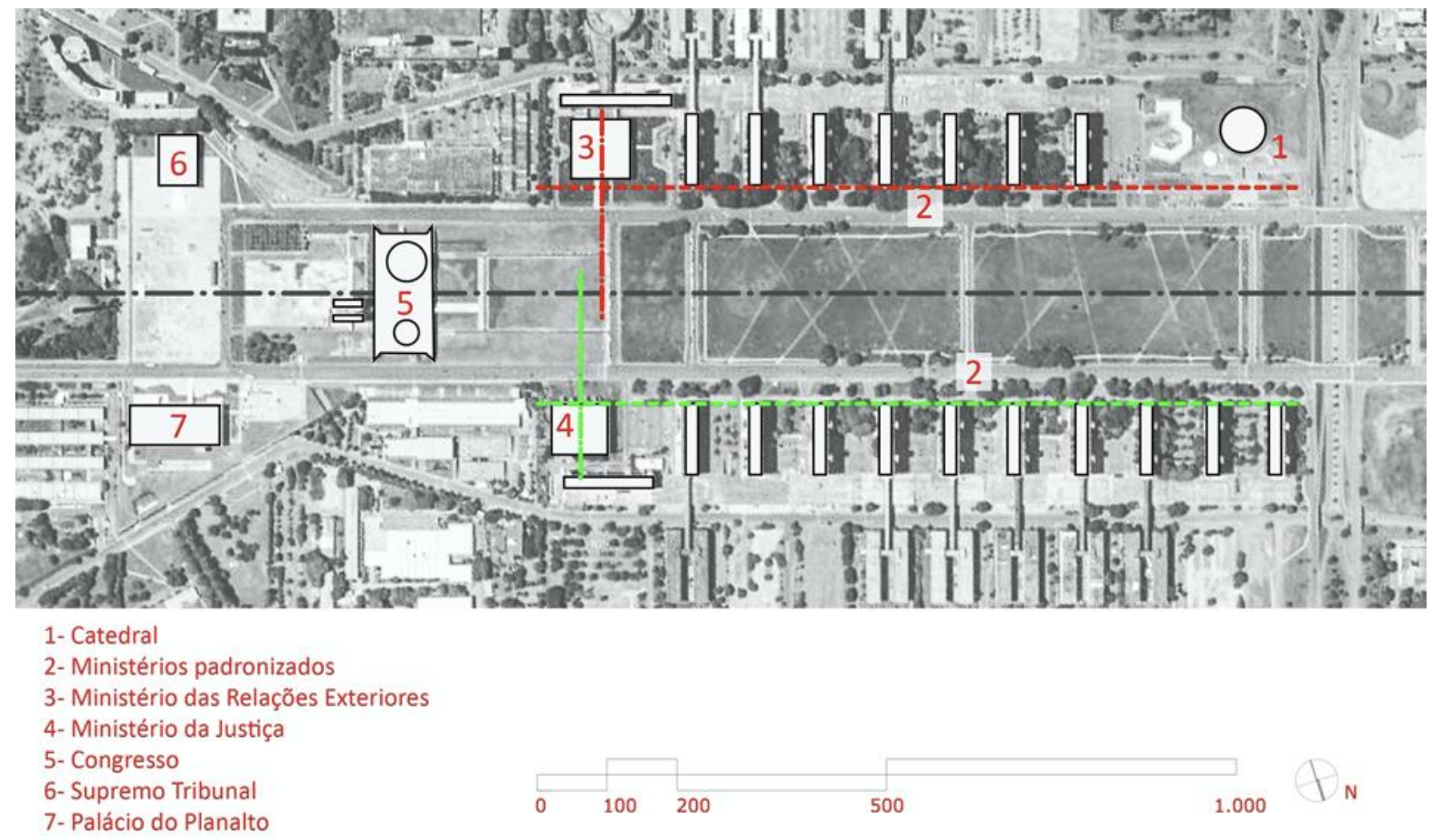

Fonte: Desenho do Autor sobre base do Google Maps

Além disso, em outra mudança em relação ao plano original de Costa, esses dois palácios deixam de ocupar posições absolutamente simétricas em relação ao eixo principal. $O$ da Justiça segue o plano de alinhamento dos demais ministérios e é disposto mais próximo do Palácio do Congresso, enquanto o Itamaraty, alinhado pelo eixo dos demais blocos ministeriais, tem um recuo de 8 metros. As formas também não são idênticas, o Itamaraty é caracterizado por arcadas idênticas nas quatro fachadas, enquanto o Palácio da Justiça tem as quatro fachadas diferentes, sendo a principal caracterizada por semi-arcos e cascatas que jorram de cascas de concreto fixadas nos intercolúnios. As dimensões são semelhantes, mas não idênticas. O Palácio Itamaraty tem planta quadrada de 86x86m e o da Justiça tem planta retangular de $75 \times 84,70 \mathrm{~m}$. Ambos têm uma altura aproximada de $14 \mathrm{~m}$. Ainda assim, são percebidos como um par dentro do conjunto, em parte devido à localização, mas também devido à semelhança de volume e materialidade.

Solução parecida acontece na Praça dos Três Poderes, entre os palácios do Planalto e o do Supremo Tribunal Federal. Ambos adotam um desenho parecido de coluna, têm a mesma materialidade, mas no Planalto as colunas são dispostas nas fachadas norte e sul e, no Supremo, nas fachadas leste e oeste. Outra mudança importante em relação ao desenho de Lucio Costa é vista no Palácio do Congresso, que passa a ter duas cúpulas e duas torres, ao invés de uma, para atender à exigência de separação das casas. A cúpula do Senado é voltada para baixo, a da Câmara dos Deputados é maior e invertida. Para equilibrar a composição, Niemeyer desloca as torres em direção à cúpula menor. Esse jogo entre nivelamento e aguçamento, presentes tanto na proposta original de Lucio Costa, quanto nas modificações realizadas por Oscar Niemeyer demonstra o domínio e sensibilidade dos arquitetos na lida com as formas, trazendo vitalidade e movimento à composição, sem perder o sentido de ordem e de conjunto. 
Apesar de apoiarmos nossa análise, até o momento em imagens planificadas, é essencial a confirmação desses efeitos a partir do ponto de vista do observador, preferencialmente em movimento. É importante ressaltar que o movimento adquire especial importância na arquitetura moderna, como ressalta Mario Pedrosa no texto que dá continuidade à epígrafe deste artigo:

Em razão de muitos fatores, complexíssimos, de ordem sensível, técnica, cultural, histórica, nenhum daqueles elementos [massa, linha, cor, espaço] exerce, hoje, no nosso tempo, maior fascínio sobre nós do que o espaço. [...] E como o percebemos? Frontalmente, parado, diante de uma fachada? É claro que não. Percebemo-la [a arquitetura] em movimento, de múltiplos ângulos. (PEDROSA, 1981, p. 279)

E, com efeito, em Brasília, à diferença da maioria das cidades tradicionais, essa nova concepção espacial é levada ao extremo. Lá podemos circular praticamente em torno de qualquer edifício da área central da cidade, mas é importante levar em conta que esse deslocamento nem sempre é feito a pé, mas também de automóvel.

Nesse sentido, tratar o Eixo Monumental como uma linha ideal, pode ser enganoso. É preciso considerar também o ponto de vista do observador a partir das vias de trânsito, que são deslocadas $100 \mathrm{~m}$ desse eixo. O sentido do tráfego também influi na ordem da percepção dos edifícios. Ao fazer o percurso de automóvel no sentido oeste-leste, em direção à Praça dos Três Poderes, vemos, à nossa direita, a Catedral de Brasília, sete blocos ministeriais iguais e regularmente espaçados, e o Palácio Itamaraty, nesta ordem. Chegando à borda do tabuleiro, próxima ao Congresso, uma rampa em declive leva o automobilista à Praça dos Três Poderes, que está situada em um terrapleno cerca de $10 \mathrm{~m}$ mais baixo. No sentido inverso, subimos a rampa que conduz ao tabuleiro da Esplanada e vemos - Ministério da Justiça em primeiro lugar e, em seguida, o desfile de 10 blocos ministeriais padronizados. (Figuras 10 e 11)

Figuras 10 e 11: Vista dos edifícios a partir do Eixo Monumental (acima a vista Sul e abaixo a vista norte).
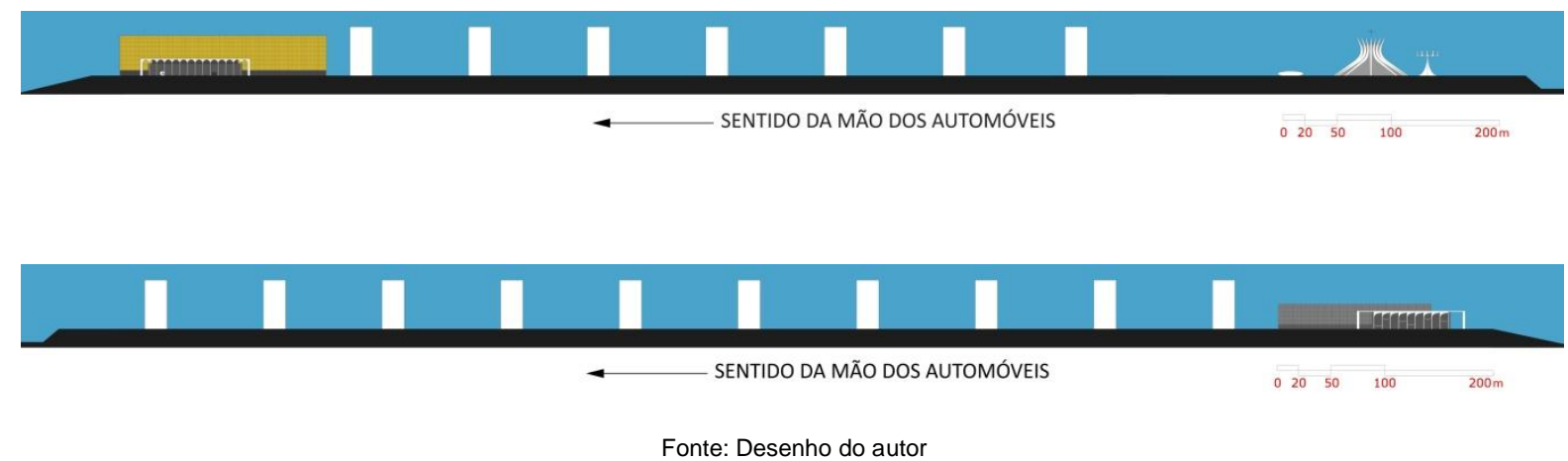

Assim, a visão ideal, centralizada da Esplanada dos Ministérios não é tão comum, e acontece praticamente em duas situações: a partir da Plataforma Rodoviária ou do mirante da Torre de TV, ambos situados a oeste da Esplanada dos Ministérios e em um nível mais alto. No entanto, normalmente a apreensão visual do conjunto se dá percorrendo a Esplanada fora do eixo de simetria, a partir das vias de trânsito e calçadas laterais. Para percorrer a esplanada sobre eixo ideal, deveríamos fazê-lo a pé, atravessando o gramado do canteiro central, o que não é uma caminhada das mais agradáveis.

Com isso, podemos afirmar que existe uma hierarquia entre os edifícios dispostos de um lado ou do outro do eixo, de acordo com o sentido do tráfego e a visão do automobilista. Há quem chame de lado 
A e lado $\mathrm{B}$ da Esplanada. Os que estão do lado sul do eixo têm maior destaque, pois correspondem à leitura preferencial da composição, que parte da Rodoviária e culmina nas torres do Palácio do Congresso. Deste lado estão: a Catedral, 7 blocos e, enfim o Palácio Itamaraty. A sequência do lado norte da Esplanada, por sua vez, é menos dramática, pois começa com o edifício mais importante, o Palácio da Justiça, seguido pelo desfile monótono dos ministérios padronizados. E se no "Mall dos ingleses" tivéssemos também a mão inglesa, os edifícios teriam sido projetados do mesmo modo?

\subsection{A composição no lote}

Atrás do Palácio Itamaraty, olhando a partir do Eixo Monumental, situa-se o bloco administrativo ou Anexo I, perpendicular aos demais ministérios. A fachada voltada para o Eixo é coberta por brises metálicos verticais pintados na cor amarela e funciona como pano de fundo para o Palácio. Os dois edifícios são conectados por passarelas situadas no segundo nível. Atrás do Anexo I, em lote rebaixado, situado do outro lado da rua de serviço, encontra-se o Anexo II, projetado posteriormente. Mesmo sendo conectado ao Anexo I por uma passarela, esse segundo anexo dificilmente é percebido como parte do complexo, exceto nas imagens aéreas ou no percurso interno. Portanto, nos detivemos na análise da composição do palácio e primeiro anexo.

A disposição do Palácio não obedece ao espaçamento rigoroso de $75,6 \mathrm{~m}$ verificado entre os blocos dos demais ministérios. $O$ edifício está distanciado cerca de $80 \mathrm{~m}$ do bloco ministerial mais próximo. $\mathrm{O}$ ritmo é recuperado, no entanto, na extremidade leste do Anexo I (Figura 12). Essa retomada do ritmo nos faz repensar na analogia que fizemos com a música de João Gilberto, mestre no descompasso entre a voz e a batida do violão.

Figura 12: Implantação do Ministério das Relações Exteriores

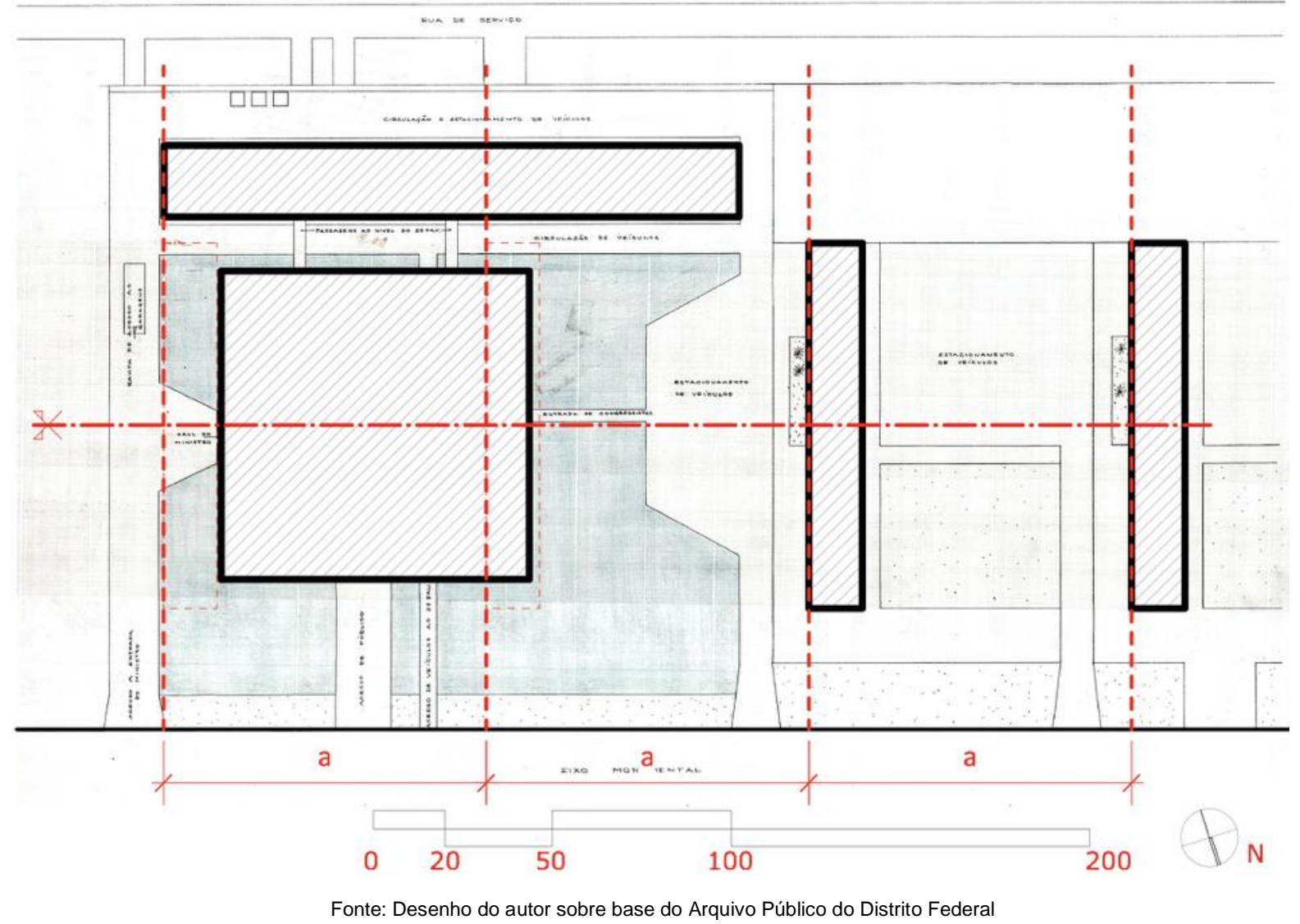


A assimetria do palácio em relação ao anexo, por sua vez, tem origem em versões anteriores do projeto, quando havia a intenção de se criar uma praça entre o Palácio, o Anexo e o Ministério da Saúde, como se observa na foto da maquete publicada em 1959 na revista Brasília (Figura 13). Com o desenvolvimento do projeto, o palácio se aproximou do bloco do Ministério da Saúde e, por questões de segurança, a ideia da praça foi definitivamente por água abaixo com a criação do espelho d'água.

Figura 13: Segunda versão do projeto para o Ministério das Relações Exteriores, Oscar Niemeyer, 1959.

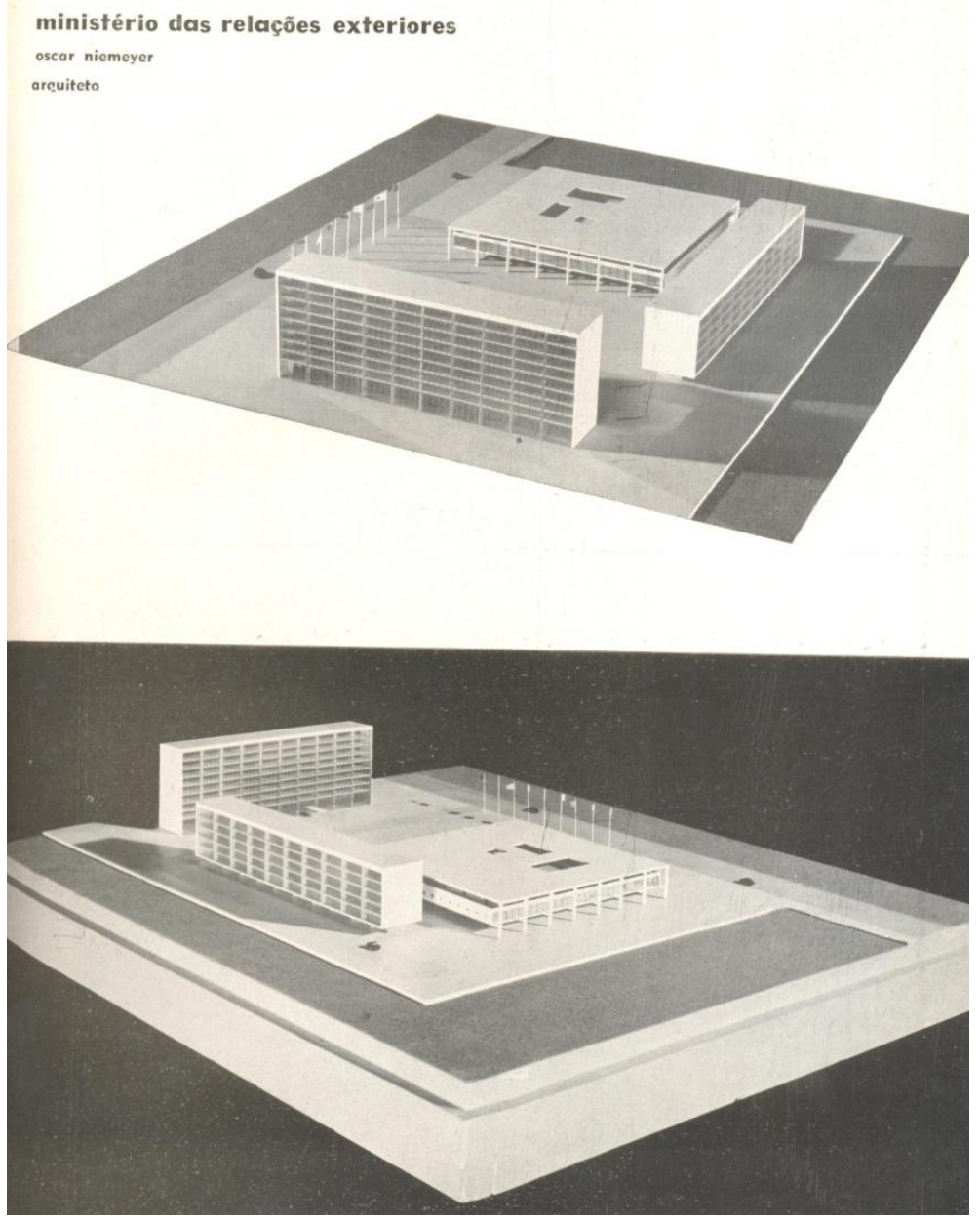

Fonte: Brasília: revista da Companhia Urbanizadora da Nova Capital do Brasil : Ano 3, n. 30 (jun. 1959). p. 15.

No entanto, mesmo após o desaparecimento da praça e a aproximação do palácio ao ministério da Saúde, o edifício não foi centralizado no lote. Esse "respiro" mantido em relação bloco vizinho e a ampla área de reflexo no espelho d'água resultante nesse espaço, denota a intenção do arquiteto em eleger uma visada preferencial no canto noroeste do lote (Figura 14). 
Figura 14: Visada do conjunto a partir do canto noroeste do lote

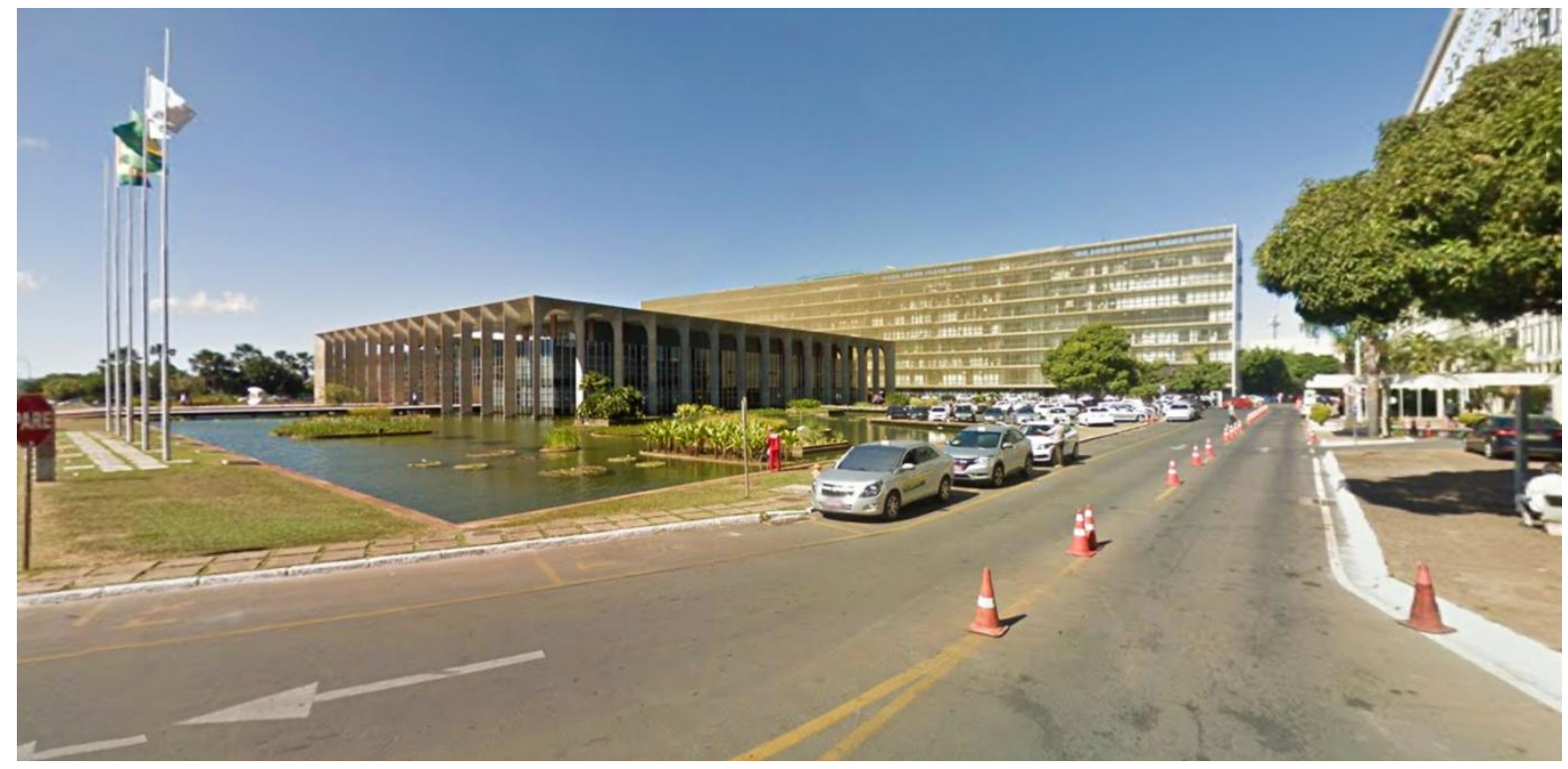

Fonte: Google Street View

\subsection{A composição das fachadas do Palácio}

A entrada principal do Palácio Itamaraty se dá por uma passarela longa 30 metros que parte da pista de automóveis e conduz o visitante sob os arcos até o corpo do edifício, uma caixa de vidro recuada em relação às arcadas de concreto aparente. A estrutura das arcadas é simétrica nos dois eixos e as quatro fachadas são praticamente idênticas. Seus $86 \mathrm{~m}$ de largura são subdivididos em 14 arcos estrombados ${ }^{8}$ de superfície complexa, com um passo de $6 \mathrm{~m}$, que partem de dentro do espelho d'água e se elevam $14 \mathrm{~m}$ a partir do nível da água. Os arcos impõem um ritmo regular às fachadas e os pilares de canto são dispostos a $45^{\circ}$ de modo a manter a regularidade das quatro fachadas (Figura 15). A superfície do intradorso dos arcos resulta da concordância da forma curva, no plano interno da arcada, com a forma retangular no plano externo (Figura 16).

Figura 15: Fachada principal do conjunto

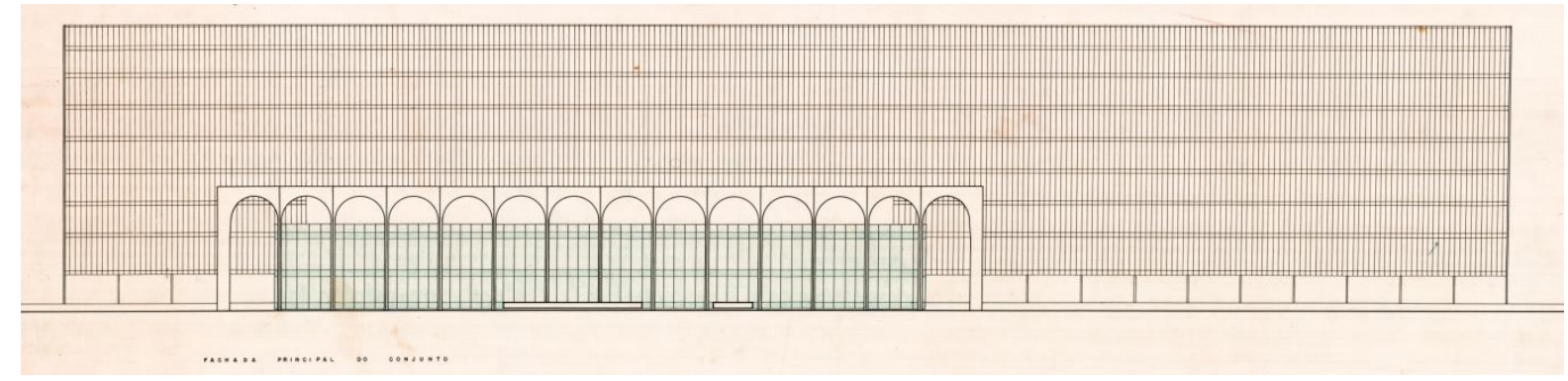

Fonte: Arquivo Público do Distrito Federal

\footnotetext{
${ }^{8} \mathrm{O}$ termo de origem italiana é strombato, ou seja, em forma de tromba. A strombatura ou strombo é a abertura das molduras de portais, janelas ou seteiras com o aumento da amplitude em direção ao externo de modo a garantir maior entrada de luz, mas também por motivos decorativo com a utilização jambas e arquivoltas. Traduzimos aqui o termo strombato por estrombado e strombatura por estrombamento. Cf. (PEVSNER; FLEMING; HONOUR, 1981)
} 
Figura 16: Esquema geométrico tridimensional dos arcos centrais.
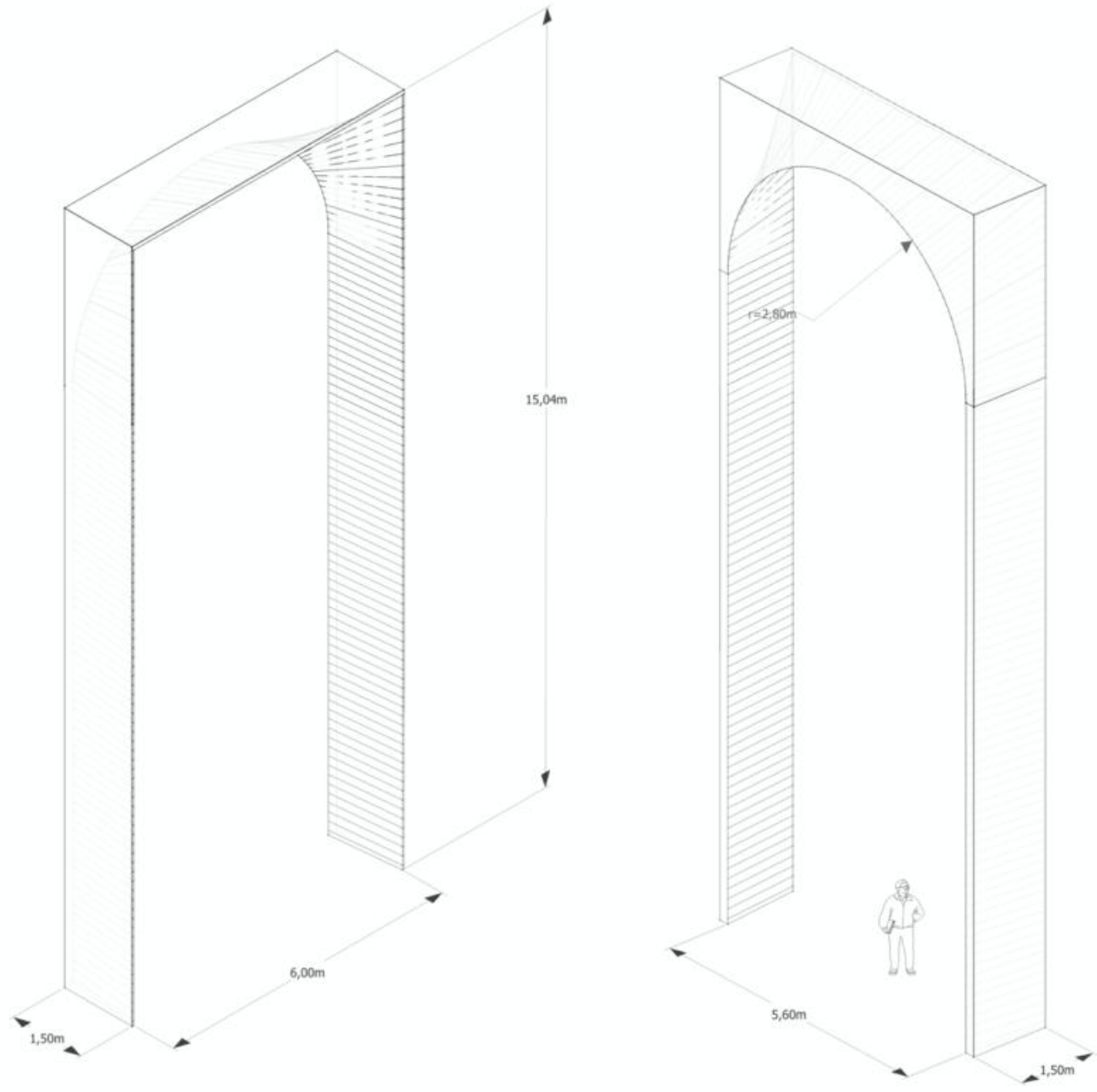

Fonte: Desenho do autor

As curvas dos arcos extremos têm pontos de arranque desnivelados (Figura 17). Essa correção visual foi aplicada por Milton Ramos após perceber, desenhando a fachada em escala ampliada, que os pilares das extremidades davam a sensação de abertura em direção ao alto, como afirma o arquiteto em depoimento (RAMOS, 1996). Essa técnica de correção visual, conhecida como êntase, remonta à arquitetura antiga dos gregos e consiste em inclinar as colunas das extremidades para dar a impressão de verticalidade ao observador. Enfim, para se certificar do efeito final da curva e estudar a execução da fôrma, Ramos constrói um protótipo em escala real de um trecho da arcada (Figura 18). 
Figura 17: Detalhe dos arcos com correção visual aplicada no arco da extremidade.

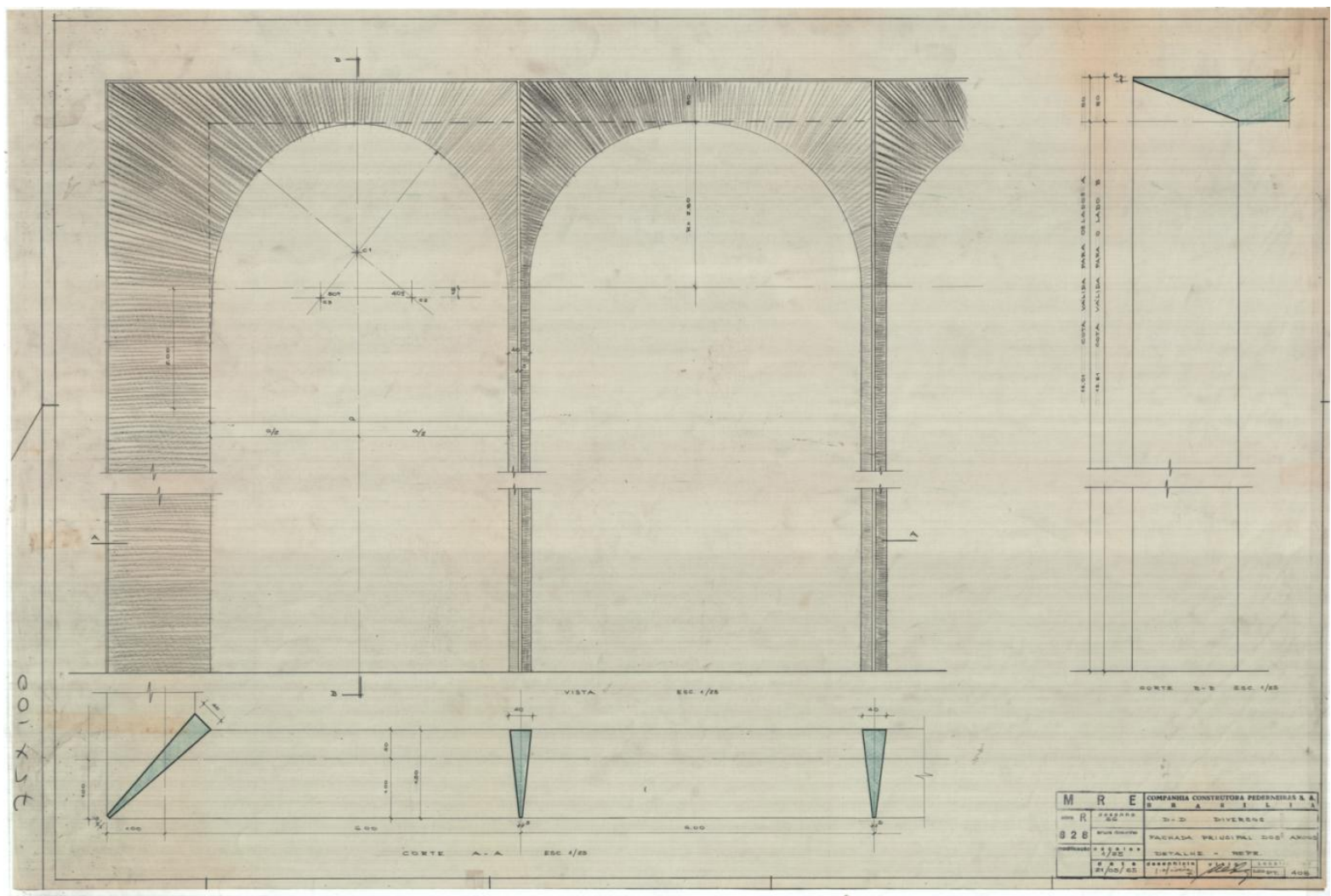

Fonte: Arquivo Público do Distrito Federal 
Figura 18: Protótipo dos arcos em escala 1:1

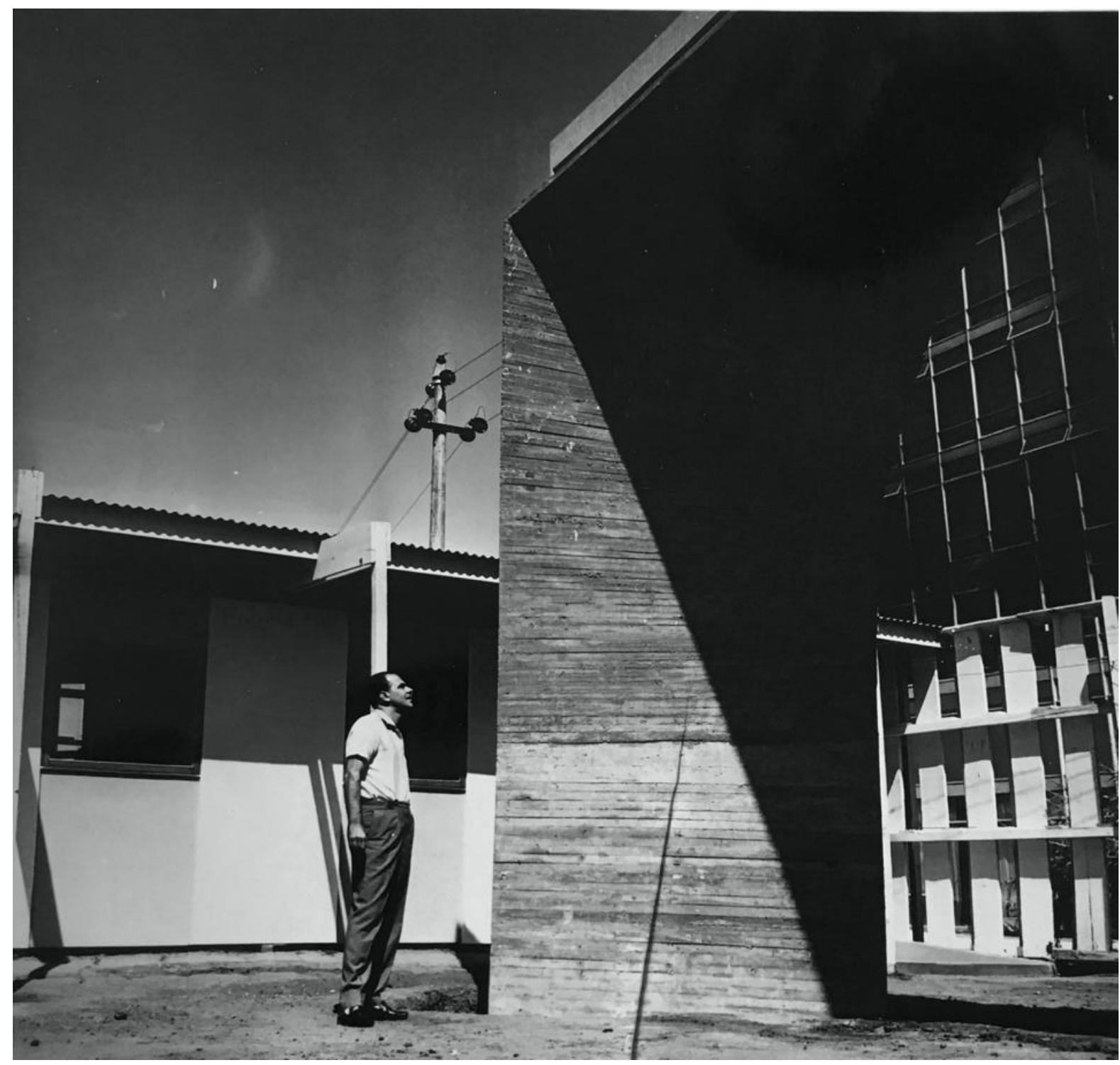

Foto: Milton Ramos

Dentro da estrutura do peristilo se aninha a caixa de vidro fumê do corpo do edifício. A envoltória de vidro é recuada do plano interno das arcadas e destacada do teto, dando assim a impressão de que o teto é sustentado somente pelas arcadas, sem contato com o corpo principal. Para enfatizar esse efeito, os pilares internos, que partem da caixa de vidro para sustentar a cobertura são recuados e revestidos de madeira, o que Ihes dá caráter de painel, mais do que de estrutura.

A hierarquia das fachadas do palácio é definida pela relação com a rua principal, pela colocação assimétrica do edifício no espelho d'água, como já explicamos, pela posição do volume anexo, que cria uma relação figura e fundo e, por fim, pela a escultura Meteoro de Bruno Giorgi (Figura 19), posicionada lateralmente à rampa de acesso principal enfatizando o efeito de aguçamento já observado na assimetria entre os blocos. 
Figura 19: Fachada principal do Palácio com a escultura Meteoro, de Bruno Giorgi.

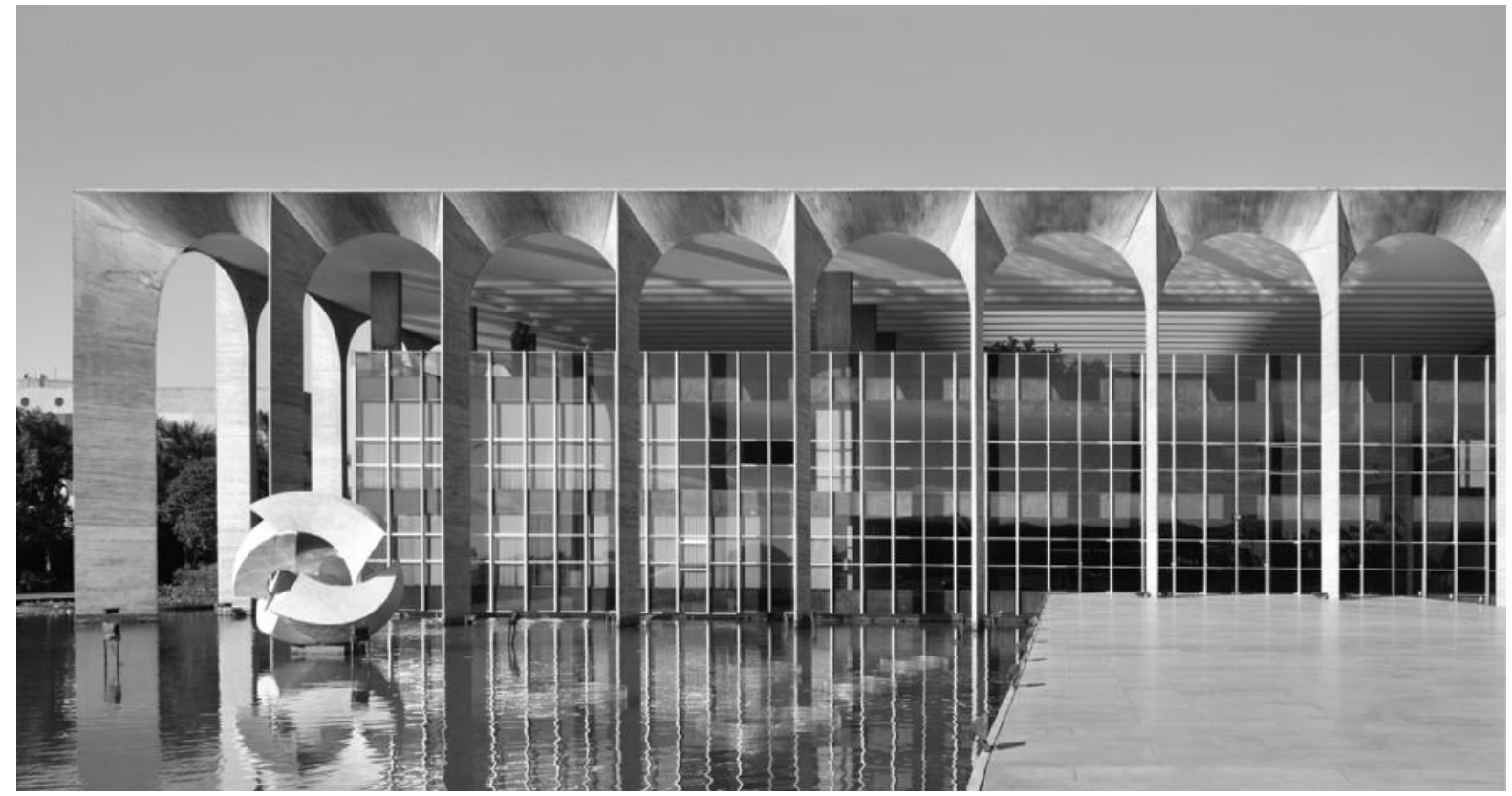

Foto do autor

\section{Considerações finais}

A partir de fundamentos da sintaxe da linguagem visual expostos por Donis A. Dondis, analisamos neste artigo alguns aspectos visuais do Palácio Itamaraty em Brasília. Partindo da observação do edifício no contexto urbano e sua relação com os demais edifícios, analisamos também as estratégias de composição dos edifícios do complexo do Ministério das Relações Exteriores no lote e das fachadas do Palácio Itamaraty. Seria interessante confrontar esses resultados com uma análise da experiência interna, mas entendemos que para isso seria importante adotar outros métodos investigativos, uma vez que ali concorrem mais fortemente outros sentidos além da visão.

Nas diversas escalas analisadas, pudemos observar que a composição volumétrica do Eixo Monumental tem como referência a ordenação simétrica. Porém, as quebras de ritmo, desalinhamentos e mudanças de padrão, provocam o aguçamento da percepção, tornando a composição mais rica e interessante. Essas estratégias de contraste e aguçamento são dosadas com parcimônia, de modo a não comprometer a leitura ordenada do conjunto e nem a compreensão do todo. Para verificar as razões do "sucesso estético" do Palácio Itamaraty, gostaríamos de enfatizar a importância de se observar o edifício no contexto urbano em relação aos percursos do observador. Vimos que o destaque do palácio na composição é resultado do contraste com os demais ministérios, mas também é devido à sua posição privilegiada na ordem da leitura da composição do Eixo Monumental, que parte da Plataforma Rodoviária em direção à Praça dos Três Poderes. Notamos ainda que essas estratégias de composição convidam o espectador a estabelecer relações, fazer comparações ou mesmo expressar a predileção por um ou outro palácio. Concordamos com Lucio Costa, que no memorial do Plano Piloto afirma que "apesar da espontaneidade original, ela [a ideia do projeto] foi, intensamente pensada e resolvida” (COSTA, 1995, p. 283). 


\section{Agradecimentos}

Esta pesquisa contou com o apoio financeiro do programa Proex da Capes.

\section{Referências}

BRANDÃO, Claudio Roberto Comas. O Palácio Itamaraty em Brasília: reflexões sobre a concepção arquitetônica. Dissertação de mestrado. Rio de Janeiro: UFRJ, 2019.

BRUAND, Yves. Arquitetura contemporânea no Brasil. São Paulo: Perspectiva: 1981.

CAMPOS, Olavo Redig de. O Palácio dos Arcos. Arquitetura: revista do Instituto de Arquitetos do Brasil, Rio de Janeiro, n. 76, p. 19-23, out. 1968.

COLLINS, Peter. Los ideales de la arquitectura moderna; su evolución (1750-1950). Barcelona: Gustavo Gili, 5. ed., 1998.

COSTA, Lúcio. Lúcio Costa: Registro de uma vivência. São Paulo: Empresa das Artes, 1995.

DI MARI, Anthony; YOO, Nora. Operative design: a catalogue of spatial verbs. Amsterdam: BIS Publ., 2012.

DONDIS, A Donis. Sintaxe da linguagem visual. São Paulo: Martins Fontes, 2. ed., 1997.

GOMES, Cláudio. O eixo monumental. Acrópole, São Paulo, nos. 375/376, p. 29, jul./ago. 1970.

MACEDO, Danilo Matoso; SILVA, Elcio Gomes. Brasilia, the Palace of Congress and their urban changes. DOCOMOMO Journal, v. 43, p. 60-65, 2010.

NIEMEYER, Oscar. Como se faz arquitetura. Petrópolis: Vozes, 1986.

NIEMEYER, Oscar. Meu sósia e eu. Rio de Janeiro: Revan, 1992.

NIEMEYER, Oscar. Minha arquitetura. Rio de Janeiro: Revan, 2000.

NIEMEYER, Oscar. A imaginação na arquitetura. Módulo, Rio de Janeiro, n. 15, p. 6-15, out. 1959.

NIEMEYER, Oscar. Espaço arquitetural. Módulo, Rio de Janeiro, n. 50, p. 54-61, ago./set. 1978.

NIEMEYER, Oscar. Método de trabalho. Módulo, Rio de Janeiro, n. 58, p. 86-89, abril 1980.

NIEMEYER, Oscar. Trecho de entrevista. Módulo, Rio de Janeiro, n. 50, p. 43, dez. 1975.

PEDROSA, Mario. Dos murais de Portinari aos espaços de Brasília. São Paulo: Perspectiva, 1981.

PEREIRA, Miguel Alves. Arquitetura, texto e contexto. Brasília: Editora UnB, 1997.

PEVSNER, Nikolaus; FLEMING, John; HONOUR, Hugh. Dizionario di architettura. Tradução: Renato Pedio. Turim: Einaudi, 1981.

RAMOS, Milton. Memória do Arquiteto de Brasília - Milton Ramos. Produção do Instituto de Arquitetos do Brasil - Departamento do Distrito Federal, 1 DVD (ca. 80min). Brasília: IAB-DF, 1996.

ROSSETTI, Eduardo Pierrotti; RAMOS, Graça. Palácio Itamaraty: a arquitetura da diplomacia. Brasília: ITS, 2017.

UNDERWOOD, David. Oscar Niemeyer e o modernismo de formas livres no Brasil. São Paulo: Cosac Naify, 2002, p. 92. 


\section{Claudio Roberto Comas Brandão}

Arquiteto e Urbanista formado pela Universidade de Brasília - UnB (1997) e mestre em Arquitetura pela Universidade Federal do Rio de Janeiro - UFRJ (2019). Tem especialização em Desenho Industrial pela Scuola Politecnica di Design de Milão, Itália (1998). Tem experiência na área de Arquitetura, com ênfase em Projeto de Interiores e Design de Mobiliário. Atualmente cursa o doutorado em arquitetura na Universidade Federal do Rio de Janeiro pelo Programa de Pós-graduação em Arquitetura PROARQ. Sua pesquisa está inserida no projeto "Arquitetura e arquitetos brasileiros - séculos XIX e $X X$ " que faz parte da área de Patrimônio, teoria e crítica da arquitetura e da linha de pesquisa Teoria e ensino de arquitetura.

Como citar: BRANDÃO, Carlos Roberto Comas. O Palácio Itamaraty em Brasília: uma análise a partir da sintaxe da linguagem visual. Revista Paranoá. n.29, jan/jun 2021. DOI 10.18830/issn.16790944.n29.2021.06

Editor: Carlos Henrique Lima 